CZASOPISMO INŻYNIERII LADOWEJ, ŚRODOWISKA I ARCHITEKTURY JOURNAL OF CIVIL ENGINEERING, ENVIRONMENT AND ARCHITECTURE

JCEEA, t. XXXII, z. 62 (3/I/15), lipiec-wrzesień 2015, s. 531-539

\author{
Monika ZDEB ${ }^{1}$ \\ Dorota PAPCIAK ${ }^{2}$ \\ Justyna ZAMORSKA ${ }^{3}$ \\ Małgorzata MIĄSIK
}

\title{
QUALITY ASSESSMENT OF HEALING MINERAL WATER USING A VARIETY MEASUREMENT TECHNIQUES
}

\begin{abstract}
Medicinal water can be, like all groundwater, appearing in the environment are constantly changing, which are both natural and caused broadly defined anthropopressure. In the case of medicinal waters, any changes to lower their health effects on the human organism are unfavorable. Consequently it is need for periodic testing of their terms of physico-chemical parameters, including mineral composition. The aim of this study was to determine the physicochemical parameters and assess the quality of 16 selected medicinal mineral waters found health resorts Rymanów Zdrój and Iwonicz Zdrój, and the possibility apply new techniques for the determination of the elemental composition of the water. The results of the elemental composition was undertaken using ion chromatography and X-ray fluorescence. For the latter indications additionally introduced variant hydrochloric acid treatment of the sample due to the high concentrations of chlorides in the test waters. Research has shown the presence of inter alia bar or niobium, elements that were not declared composed of the pump-and bottlers, in higher concentrations could cause such. intestinal cramps, muscle relaxation, and in extreme cases, paralysis of the respiratory center. Their adverse effect may be compounded by the use of inhaled therapeutic. Over this demonstrated significant differences in the quantitative composition of key elements, depending upon the method of determination. The results obtained allowed the calculation of indicators of water hydrochemical and their classification according to the Sulina Scale. The correctness of the analyzes concentrations of elements was confirmed balance of cations and anions. Based on pooled data was evaluated therapeutic properties of mineral waters and the possibility of their use in therapy.
\end{abstract}

Keywords: medicinal mineral water, scale of Sulin, ion chromatography, X-ray fluorescence

\footnotetext{
${ }^{1}$ Corresponding author/Autor do korespondencji: Monika Zdeb, Rzeszów University of Technology, Department of Water Purification and Protection, al. Powstańców Warszawy 12, 35-086 Rzeszów, telephone: 017865 1949, e-mail: mzdeb@prz.edu.pl

2 Dorota Papciak, Rzeszów University of Technology

3 Justyna Zamorska, Rzeszów University of Technology

${ }^{4}$ Małgorzata Miąsik, Rzeszów University of Technology
} 


\section{Introduction}

The healing properties of groundwater already appreciated in ancient Greece and Rome, where the use of baths for health purposes. Only in the seventeenth century started to be used medical treatments consisting in drinking water and inhalations. Now, after a period of decline of interest in balneology observes its new prosperity.

Groundwater, depending on the location, depth and persistence, degree of mineralization and the environment, characterized by different medicinal properties. They have among other things, direct action governing the digestive system, support the treatment of infections and chronic respiratory diseases, inhibit the process of osteoporosis, prevent tooth decay, reduce inflammation of joints, and nerve pain, treat anemia, as well as enhance overall immunity. However, due to the high degree of mineralization, most of these waters is not suitable for everyday consumption, and only some of them are bottled and available for the general public. In Poland at present for deposits of medicinal waters is considered to 70 underground water deposits, of which 4 in Podkarpacie [1]. The spas Rymanow Zdroj Iwonicz Zdroj and mineral water are derived mainly from natural sources and artificial wells. Because of the composition and proportions of minerals they belong to the waters chloride sodium bicarbonate and water. In addition to krenoterapii water they are used for medicinal baths, inhalation and so-called. wrappings. Only one water of Rymanow Zdroj (Celestine) is bottled, and others are available only at drinking fountains or in the sanatoriums. Natural mineral water is water from proved reserves of underground water, mined one or more natural or drilled wells, originally pure in terms of chemical and microbiological, characterized by a stable mineral composition and properties of relevance physiologically, causing, well-defined preferred effects on human health [2]. Therefore, there is a fixed need for quality control of medicinal water in a wide range of parameters both on the microbiological quality and chemical composition and physical. The aim of this study was to determine the physicochemical parameters of the sixteen selected medicinal mineral waters, occurring in spas Rymanow Zdroj, including Iwonicz Zdroj using new techniques for determining the elemental composition of water and quality assessment in the context of its use for medicinal purposes.

\section{Methods}

Mineral waters subject to study came from 11 intakes, located in the village of Rymanow Zdroj health resort and 5 intakes from areas Iwonicz. Samples were taken at drinking fountains of mineral water to polyethylene bottles and immediately transported to the laboratory. The basis for assessing the quality of the tested waters are the results of physicochemical analyzes specified in the 
Regulation of the Council of Ministers of 14 February 2006 on groundwater deposits classified as brines, curative and thermal and other curative minerals deposits, as well as common minerals examination of certain deposits or geological units basic minerals (tab.1). The analysis of ions by X-ray fluorescence was made in two versions: the classical and apply a sample of hydrochloric acid, because of the high concentration of chloride. In order to control the quality and accuracy of the results, the samples which indicate all the cations and anions, ion balance made in accordance with PN-89/C-04638.02.

Table 1. Causes and types of cast iron pipelines failures

Tabela 1. Relacje rodzajowo-skutkowe uszkodzeń dla przewodów z żeliwa

\begin{tabular}{|c|l|l|l|l|}
\hline Lp. & Badany wskaźnik & Jednostka & $\begin{array}{l}\text { Metoda badawcza / urządzenie } \\
\text { badawcze }\end{array}$ & Procedura badawcza \\
\hline 1 & $\mathrm{pH}$ & - & $\begin{array}{l}\text { Metoda potencjometryczna/ } \\
\text { pehametr HQ40d multi- elek- } \\
\text { troda pH, Hach Lange }\end{array}$ & $\begin{array}{l}\text { PN-90/C- } \\
04540.01\end{array}$ \\
\hline 2 & przewodność & $\mathrm{mS} / \mathrm{cm}$ & $\begin{array}{l}\text { Miernik przewodności HQ40d } \\
\text { multi - elektroda przewodności/ } \\
\text { Hach Lange }\end{array}$ & $\begin{array}{l}\text { PN-EN } \\
27888: 1999\end{array}$ \\
\hline 3 & twardość & $\mathrm{mval} / \mathrm{dm}^{3}$ & $\begin{array}{l}\text { Metoda miareczkowa (metoda } \\
\text { wersanianowa) }\end{array}$ & $\begin{array}{l}\text { PN-ISO } \\
6059: 1999\end{array}$ \\
\hline 4 & zasadowość & $\mathrm{mval} / \mathrm{dm}^{3}$ & $\begin{array}{l}\text { Metoda miareczkowa wobec } \\
\text { wskaźników }\end{array}$ & $\begin{array}{l}\text { PN-C-04540-03: } \\
1999 / \mathrm{AZ1}: 2003 \mathrm{P}\end{array}$ \\
\hline 5 & wolny CO2 & $\mathrm{mval} / \mathrm{dm}^{3}$ & $\begin{array}{l}\text { Metoda miareczkowa roztwo- } \\
\text { rem wodorotlenku sodu w obec- } \\
\text { ności fenoloftaleiny }\end{array}$ & PN-C-04547.01 \\
\hline 7 & $\begin{array}{l}\text { mętność } \\
\text { barwa }\end{array}$ & NTU & $\begin{array}{l}\text { Mętnościomierz 2100P, Hach } \\
\text { Lange }\end{array}$ & PN-EN ISO7027 \\
\hline 8 & $\begin{array}{l}\text { analiza jonów } \\
\text { Na, Cl, K, Ca, } \\
\text { Gr, Br, } \mathrm{Zn}, \mathrm{Ga}, \mathrm{I}, \mathrm{Ba}, \\
\mathrm{Mg}, \mathrm{Cu}, \mathrm{P}, \mathrm{S}, \mathrm{Ni}, \\
\mathrm{Cr}, \mathrm{Pb}, \mathrm{Ru})\end{array}$ & hazen & $\begin{array}{l}\text { Metoda kolorymetryczna/ Aqu- } \\
\text { aquant 14421, Merck }\end{array}$ & PN-74/C-04548 \\
\hline
\end{tabular}

Hydrochemical analysis of water surveyed performed using water classification scale called Sulina, which distinguishes four basic types of water:

- hydrocarbonate - sodium $\left(\mathrm{HCO}_{3}-\mathrm{Na}^{+}\right)$,

- sulphate - sulfate $\left(\mathrm{SO}_{4}{ }^{2-}-\mathrm{Na}^{+}\right)$,

- chloride - magnesium $(\mathrm{Cl}-\mathrm{Mg})$,

- chloride - calcium $(\mathrm{Cl}-\mathrm{Ca})$. 


\section{Results and discussion}

The chemical composition of groundwater depends on many factors and changes with time. In the case of waters used as medicinal waters from the correct designation of qualitative and quantitative elements sometimes it depends on the health and lives of patients. The graphs 1 and 2 show the contents of ions randomly selected therapeutic waters. The results obtained using different measurement techniques were compared with the data declared by the water pump rooms. Both waters in Rymanow Zdroj as well as those of Iwonicz contain prevalence sodium, calcium, chlorine, potassium and magnesium. Studies using $\mathrm{X}$-ray fluorescence showed the presence of traces of elements such as germanium, strontium, bromine or bar. Especially the latter element concentrations exceeding the limits, it is worrying. The results obtained by ion chromatography proved to be most similar to those declared by the pump-room mineral waters. The use of X-ray fluorescence to detect trace quantities of elements not listed by ion chromatography. In the case of elements present in higher concentrations the results obtained by this method are much too low in relation to the indications by ion chromatography or reported. This may be because of the limitations of the detector, which is not capable of detecting very large amounts of signals coming from the ion present in relatively large concentrations [3]. However this method can be useful for detecting and monitoring changes in the concentration of trace elements, especially those hazardous to health. Biggest discrepancies compared to the data declared, was recorded for signs of Fluorescence of samples prior treatment with acid. For these determinations were the most understated performance in relation to those declarations.

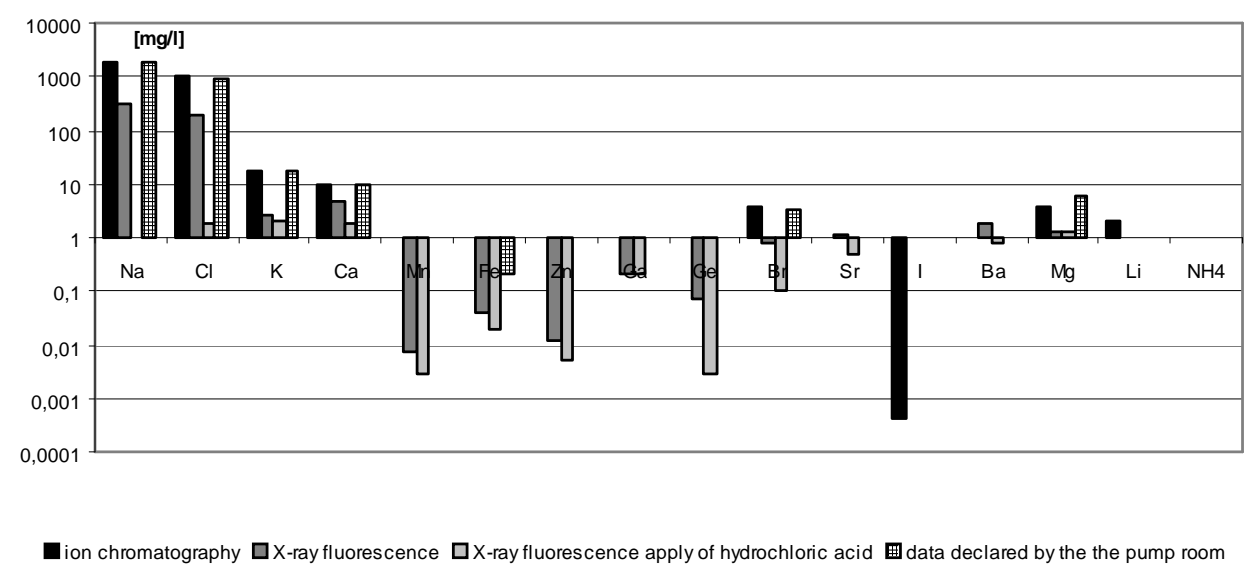

Rys. 1. Elemental composition of the Mieczysław water

Fig. 1. Skład pierwiastkowy wody Mieczysław 


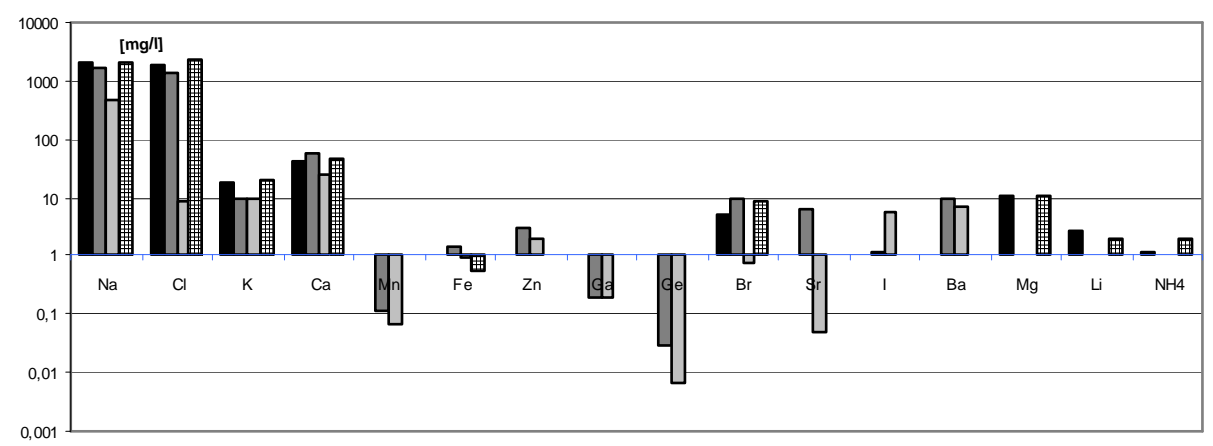

$\boldsymbol{\nabla}$ ion chromatography $\mathbf{\square}$ X-ray fluorescence $\boldsymbol{\square}$ X-ray fluorescence apply of hydrochloric acid $\boldsymbol{\square}$ data declared by the the pump room

Rys. 2. Elemental composition of the Elin 7 water

Fig. 2. Skład pierwiastkowy wody Elin 7

All the mineral waters used for medicinal purposes must comply with the number of requirements set out in Decree of the Minister of Health of 31 March on the natural mineral water, spring water and table water. In all tested waters with spa and Rymanow Zdroj Iwonicz Zdroj found exceeded for color (Fig. 3).

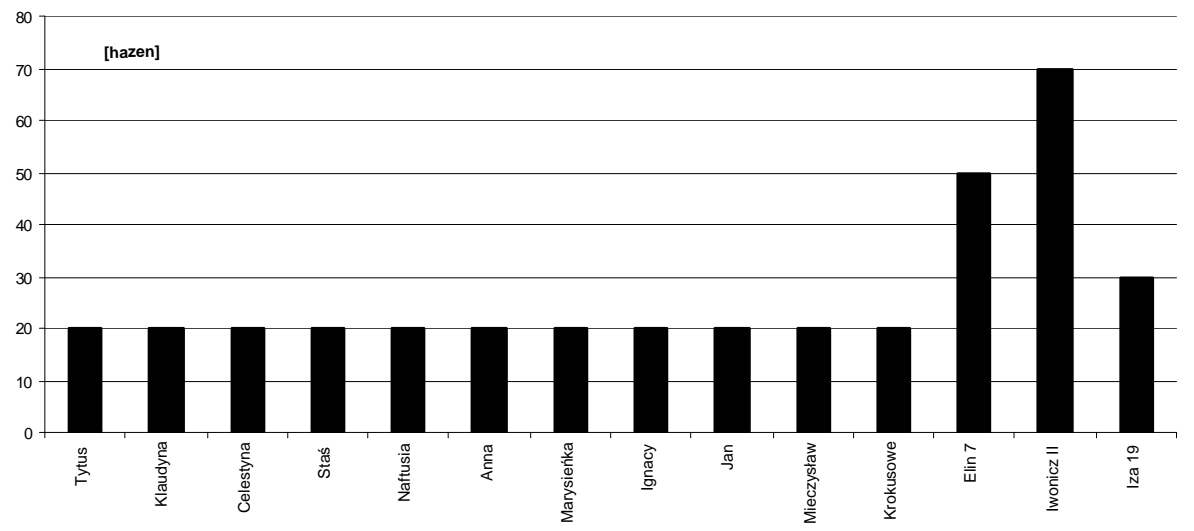

Fig. 3. The color of selected medicinal mineral waters

Rys. 3. Barwa wybranych leczniczych wód mineralnych

In the waters Titus, Klaudyna, Celestine, Stas, Naftusia, Elin 7, Iwonicz II and Klimkówka 27 were exceeded in relation to turbidity standards for drinking cures. 


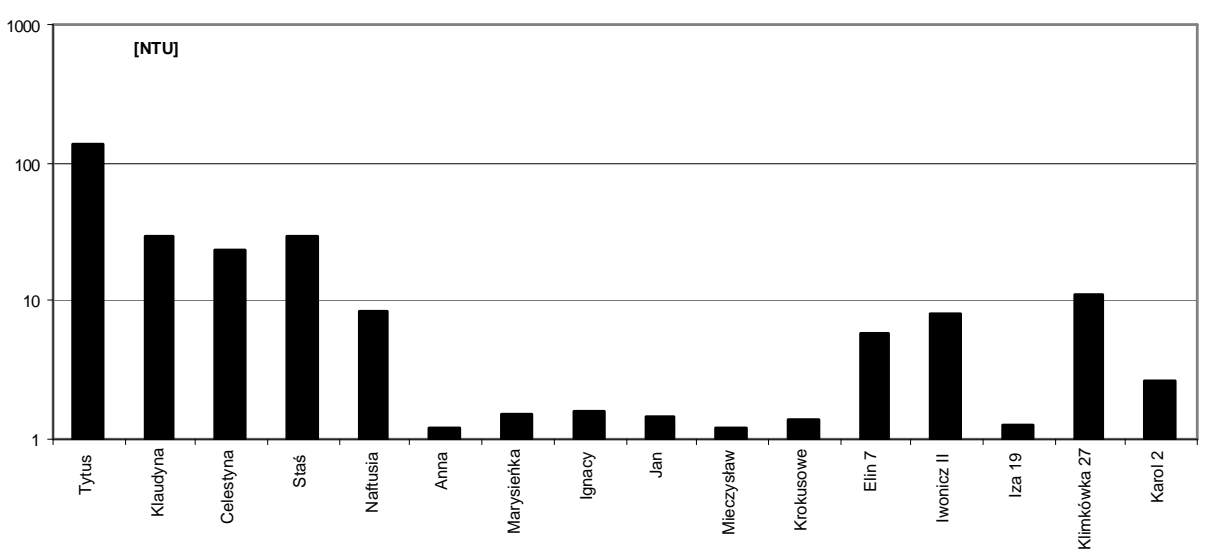

Fig. 4. Turbidity of selected medicinal mineral waters

Rys. 4. Mętność wybranych leczniczych wód mineralnych

In 4 out of 16 examined waters barium concentrations exceed the norm for inhalation (10 mg / 1), and 11 of them should be used in krenoterapii $(1 \mathrm{mg} / \mathrm{l})$ for a period longer than one month (Figure 5). Long-term consumption of water containing excessive amounts of barium salts can cause heart rhythm disturbances, muscle weakness, stomach irritation and in extreme cases, difficulty in breathing [4]. Astel et al. ascertaining the chemical composition of the popular mineral water (bottled), with ion chromatography, the said oversize of the element concentration in water Słotwinka [5].

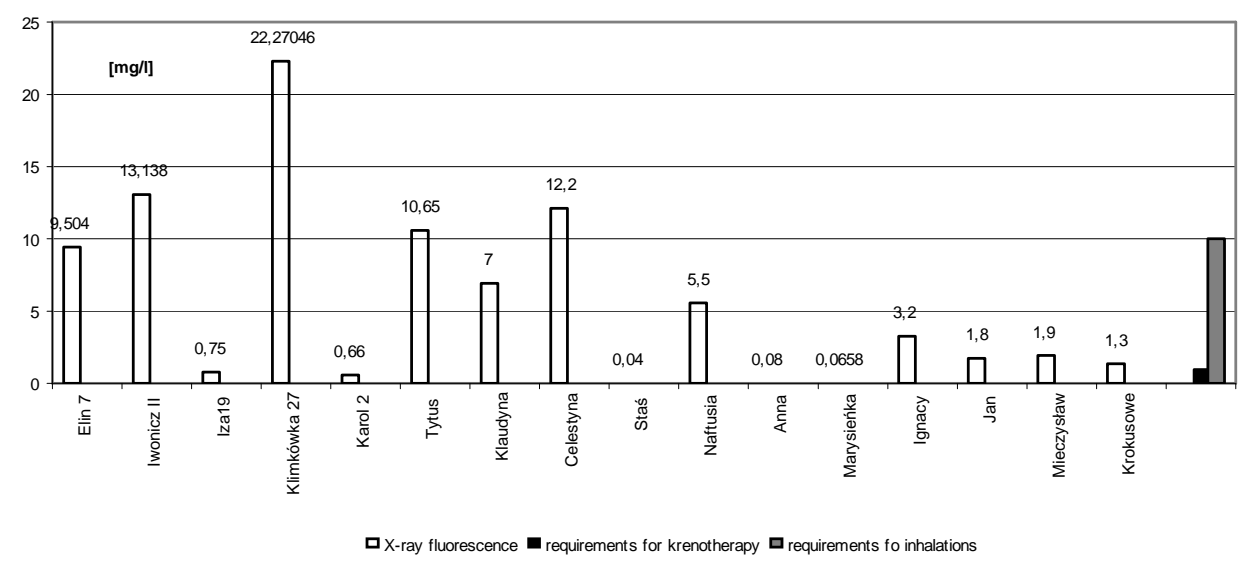

Fig. 5. The concentration of bar in the tested waters

Rys. 5. Zawartość baru w badanych leczniczych wodach mineralnych 
There are over 30 different classification systems groundwater. Most of them are based on calculations to determine the main advantage ions, or on the content of specific components. Mineral waters are used by WA Alexandrov scale or scale of Sulina. The latter classifies water due to the chemical composition and the degree of metamorphism. Table 2 summarizes the hydrochemical indices calculated according to the scale of Sulina for the test the waters. According to the classification of waters according to the scale Sulina, water, Elin 7, Iwonicz II, Klimkowka 27, we count the chloride water type magnesium. They are characterized by an average mineralization. They are referred to as relict of water transition zone. Water Iza 19, Anna, and Marysieńka this type of sulphate - sodium. These are of water young zlegające relatively shallow infiltration origin, mineralized at the level of $1-2 \mathrm{~g} / \mathrm{dm} 3$. For the waters of the carbonate - sodium mineralized 50-60 g/ dm3, are included of water: Karol 2, Titus, Klaudyna, Celestine, John, crocuses [6]. None of the water did not reveal the nature of chloride - calcium. An index value $\mathrm{rNa}+/ \mathrm{rCl}$ - over 1 testify to the fact that of water data are located in the zone of active water exchange and the ion exchange process $\mathrm{Ca} 2+$ for $\mathrm{Na}+$. Only for of water Stas value of this indicator is 0.07 and ion exchange takes place in the opposite direction [7].

Table 2. Indicators of respondents hydrochemical water according to the scale Sulina

Tabela 2. Wskaźniki hydrochemiczne badanych wód według skali Sulina

\begin{tabular}{|c|c|c|c|c|c|c|c|c|}
\hline \multirow[t]{2}{*}{ Water } & \multicolumn{2}{|c|}{$\begin{array}{l}\text { Hydrocarbonate } \\
\text { - sodium type }\end{array}$} & \multicolumn{2}{|c|}{$\begin{array}{l}\text { Sulphate - so- } \\
\text { dium type }\end{array}$} & \multicolumn{2}{|c|}{$\begin{array}{l}\text { Chloride- } \\
\text { magnesium } \\
\text { type }\end{array}$} & \multicolumn{2}{|c|}{$\begin{array}{l}\text { Chloride - calcium } \\
\text { type }\end{array}$} \\
\hline & $\begin{array}{l}\mathrm{rNa}-\mathrm{rCl} \\
/ \mathrm{SO}_{4}>1\end{array}$ & $\begin{array}{c}\mathrm{rNa} / \mathrm{rC} \\
1>1\end{array}$ & $\begin{array}{l}\mathrm{rNa}-\mathrm{rCl} \\
/ \mathrm{SO}_{4}<1\end{array}$ & $\begin{array}{c}\mathrm{rNa} / \mathrm{rC} \\
1>1\end{array}$ & $\begin{array}{l}\mathrm{rCl}-\mathrm{rNa} \\
/ \mathrm{rMg}<1\end{array}$ & $\begin{array}{c}\mathrm{rNa} / \mathrm{rC} \\
1<1\end{array}$ & $\begin{array}{l}\mathrm{rCl}-\mathrm{rNa} \\
/ \mathrm{rMg}>1\end{array}$ & $\mathrm{rNa} / \mathrm{rCl}<1$ \\
\hline Tytus & 2810,23 & 1,16 & 2910,23 & 1,16 & $-6,35$ & 1,16 & $-6,35$ & 1,16 \\
\hline Klaudyna & 2187,15 & 1,17 & 2187,15 & 1,17 & $-5,3$ & 1,17 & $-5,3$ & 1,17 \\
\hline Celestyna & 2310 & 1,13 & 2310 & 1,13 & $-5,4$ & 1,13 & $-5,4$ & 1,13 \\
\hline Staś & $-0,2$ & 0,07 & $-0,2$ & 0,07 & 0,32 & 0,07 & 0,32 & 0,07 \\
\hline Naftusia & - & 1,9 & - & 1,9 & $-15,3$ & 1,9 & $-15,3$ & 1,9 \\
\hline Anna & 0,4 & 5,25 & 0,4 & 5,25 & $-0,25$ & 5,25 & $-0,25$ & 5,25 \\
\hline Marysieńka & 0,36 & 1,45 & 0,36 & 1,45 & $-1,02$ & 1,45 & $-1,02$ & 1,45 \\
\hline Ignacy & - & 1,79 & - & $1,79.1$ & $-14,13$ & 1,79 & $-14,13$ & 1,79 \\
\hline Jan & 176,8 & 1,54 & 176,8 & 1,54 & $-2,1$ & 1,54 & $-2,1$ & 1,54 \\
\hline Mieczysław & - & 2,94 & - & 2,94 & $-167,3$ & 2,94 & $-167,3$ & 2,94 \\
\hline Krokusowe & 124,8 & 1,89 & 124,8 & 1,89 & $-15,6$ & 1,89 & $-15,6$ & 1,89 \\
\hline Elin 7 & - & - & - & - & $-38,99$ & 1,62 & $-38,99$ & 1,62 \\
\hline Iwonicz II & - & - & - & - & $-36,47$ & 1,44 & $-36,47$ & 1,448 \\
\hline Iza 19 & 0,352 & 4,04 & 0,352 & 4,04 & 0,15 & 4,04 & $-0,15$ & 4,04 \\
\hline $\begin{array}{l}\text { Klimkówka } \\
27\end{array}$ & - & - & - & - & $-29,45$ & 2,84 & $-29,45$ & 2,84 \\
\hline Karol 2 & 1,48 & 2,30 & 1,48 & 2,30 & $-3,9$ & 2,30 & $-3,9$ & 2,30 \\
\hline
\end{tabular}


Ion balance for the tested waters were made taking into account the results obtained by ion chromatography, which is defined as the most credible and the results are comparable with the data declared by the water pump rooms. Based on these data, it was found that the balance was not met for any of the water from Iwonicz and waters: Tytus, Celestyna, Staś, Anna, Marysieńka intakes from Rymanów (Figure 6).

This means that not all ions are detected and identified because of procedural flaws or insufficient sensitivity and precision elemental analysis methods used.

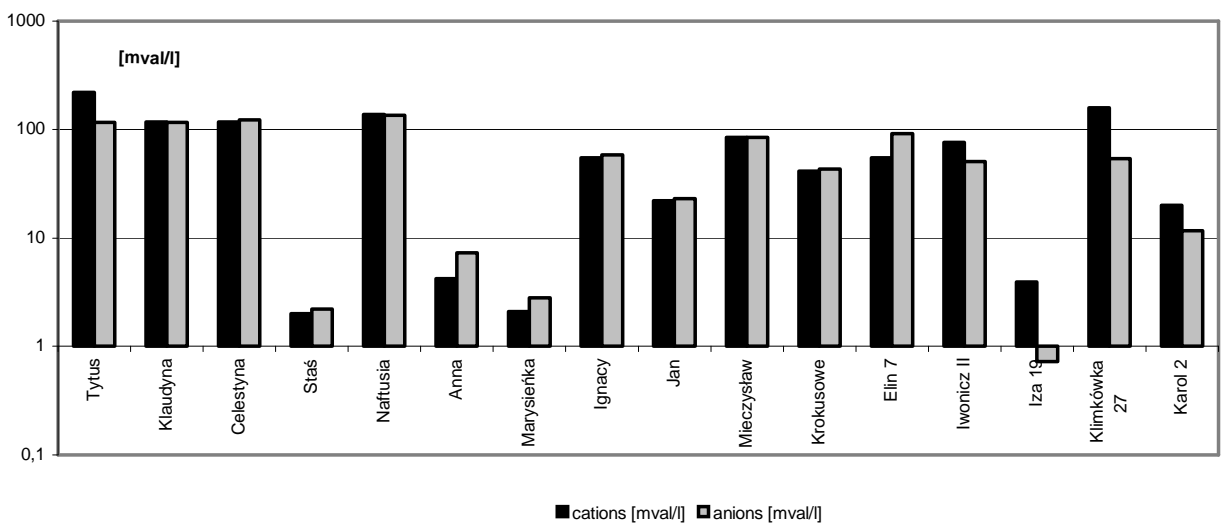

Fig. 6. The balance for the analyzed ion medicinal waters recognized in Rymanow Zdroj and Iwonicz Zdroj

Rys. 6. Bilans jonowy dla analizowanych wód leczniczych ujmowanych w Rymanowie Zdroju i Iwoniczu Zdroju

\section{Conclusion}

Ion chromatography method obtained the results of the elemental composition most similar to the declared values.

$\mathrm{X}$-ray fluorescence method allows the detection of trace quantities of elements. For most of the tested waters it has not been fulfilled ion balance, because by ion chromatography method failed to detect all ions present in the water.

According to the classification of Sulina most of the types of water comes from the transition zones or relatively shallow, which face a significant impact on the infiltration process qualitative and quantitative composition of these waters.

\section{Bibliography}

[1] Astel A., Michalski R., Łyko A., Jabłońska-Czapla M., Bigus K., Szopa S., Kwiecińska A.: Characterization of bottled mineral waters marceted in Poland using hierarchical crustel analysis, Jurnal of geochemical exploration, vol. 134, p. 136-145. 
[2] Braziewicz J., Braziewicz E., Chojnacki S., Pajek M., Semaniak J.: X-ray analysis of environmental samples 2004, Environment Monitoring Świętokrzyski Region, vol. 2, p. 39-46.

[3] Kochanowski J. W.: Balneology and hydrotherapy, wyd. AWF, 2002.

[4] Lewkiewicz-Małysa A., Wind B.: Interpretation of changes in hydro-chemical indicators based on selected chloride water, Quarrying, Petroleum, Gas, vol. 23/1, p. 2-6.

[5] Regulation of the Minister of Health of 31 March 2011 on the natural mineral water, spring water and groundwater foodstuffs (Dz. U. No. 32, item. 220).

[6] Regulation of Ministers of 14 February 2006 on groundwater deposits classified as brines, curative and thermal and other curative minerals deposits, as well as the examination of common minerals deposits from specific geological units or basic minerals (Dz. U. No. 32, pos. 220).

[7] Wind B., Lewkiewicz-Małysa A.: Medical mineral waters of Iwonicz Zdrój in focus of hydrochemical indicators research, Mineral Resources Economy, vol. 21, p. 49-67.

\section{OCENA JAKOŚCI LECZNICZYCH WÓD MINERALNYCH Z ZASTOSOWANIEM RÓŻNYCH TECHNIK POMIAROWYCH}

\section{Streszczenie}

Wody uznane za lecznicze, podobnie jak wszystkie wody podziemne, występując w środowisku podlegają ciągłym zmianom, które mają charakter zarówno naturalny jak i wywołany szeroko pojętą antropopresją. W przypadku wód leczniczych, wszelkie zmiany obniżające ich zdrowotny wpływ na organizm człowieka są niekorzystne. Stąd też wynika potrzeba ich okresowego badania względem parametrów fizykochemicznych, w tym składu mineralnego.

Celem niniejszej pracy było oznaczenie parametrów fizykochemicznych i ocena jakości szesnastu wybranych wód mineralnych leczniczych, występujących w uzdrowiskach Rymanów Zdrój oraz Iwonicz Zdrój, a także możliwość zastosowania nowych technik do oznaczania składu pierwiastkowego wody. W artykule przedstawiono wyniki analizy składu pierwiastkowego, która wykonana została $\mathrm{z}$ zastosowaniem chromatografii jonowej oraz fluorescencji rentgenowskiej. Dla tych ostatnich oznaczeń wprowadzono dodatkowo wariant $\mathrm{z}$ kwasem solnym do obróbki próbek, ze względu na wysokie stężenia chlorków w badanych wodach. Badania wykazały obecność m.in. baru czy niobu, pierwiastków, które nie znajdowały się w składzie deklarowanym przez pijalnie czy rozlewnie, a w większych stężeniach mogących powodować np. skurcze jelit, zwiotczenie mięśniowe, a w skrajnych przypadkach porażenie ośrodka oddechowego. Ich niekorzystne działanie może być potęgowane przez stosowanie inhalacji leczniczych. Ponad to wykazano znaczące różnice w składzie ilościowym kluczowych pierwiastków, w zależności od stosowanej metody oznaczania. Uzyskane wyniki pozwoliły na obliczenie wskaźników hydrochemicznych wód i ich klasyfikację według skali Sulina. Poprawność przeprowadzonych analiz ilości pierwiastków została potwierdzona bilansem kationów i anionów.

Słowa kluczowe: lecznicze wody mineralne, skala Sulina, chromatografia jonowa, fluorescencja rentgenowska

Przestano do redakcji: $12.10 .2015 \mathrm{r}$.

Przyjęto do druku: 30.10 .2015 r.

DOI: $10.7862 / \mathrm{rb} .2015 .136$ 